\title{
Hacktivist pada Pergerakan Sosial Transnasional: Kampanye Anonymous melawan Jaringan Teroris Transnasional 2015-2016 Muhammad Fikry Anshori ${ }^{1}$ \\ ${ }^{I}$ Hubungan Internasional, Universitas Padjadjaran, Jawa Barat, Indonesia
}

\section{SUBMISSION TRACK}

$$
\begin{array}{ll}
\text { Recieved } & : \text { 10 July } 2019 \\
\text { Final Revision } & : \text { 05 September } 2019 \\
\text { Available Online } & : \text { 30 November } 2019
\end{array}
$$

\section{KEYWORD}

Al-Qaeda in the Arabian Peninsula (AQAP), Anonymous, Hacktivist, Islamic State of Iraq and Syria (ISIS), Terrorist, Transnational,

Transnational Social Movement

\section{KATA KUNCI}

Al-Qaeda in the Arabian Peninsula (AQAP), Anonymous, Hacktivist, Islamic State of Iraq and Syria (ISIS), Pergerakan Sosial Transnasional, Teroris, Transnasional

\section{CORRESSPONDENCE}

E-mail : muhammad15205@mail.unpad.ac.id

\section{A B S T R A C T}

The background of this article is Anonymous's campaign activities against transnational terrorist networks. The campaign needs to be discussed because it is carried out by transnational networks against other transnational networks. This article aims to describe the characteristics of transnational social movements in the Anonymous campaign against transnational terrorist networks. The concept used in this article is the transnational social movement of S. Tarrow which focuses on four characteristics, namely political opportunities, mobilizing structure, collective action frame, and repertoires of contention. From the results of this article, it is known that the Anonymous campaign against transnational terrorist networks consists of six operations carried out during the 2015-2016 period. The operation was carried out by six hacker groups as part of the Anonymous against Al-Qaeda in the Arabian Peninsula (AQAP) and the Islamic State of Iraq and Syria (ISIS) as its targets. This article found Anonymous carried out four characteristics of the transnational social movement of S. Tarrow in six campaigns against transnational terrorist networks. Furthermore, there are distinct characteristics of Anonymous as an actor in transnational social movements.

\section{A B S T R A K}

Latar belakang artikel ini adalah aktivitas kampanye Anonymous melawan jaringan teroris transnasional. Kampanye tersebut perlu dibahas karena dilakukan oleh jaringan transnasional terhadap jaringan transnasional lainnya. Artikel ini bertujuan untuk mendeskripsikan karakteristik pergerakan sosial transnasional dalam kampanye Anonymous melawan jaringan teroris transnasional. Konsep yang digunakan dalam artikel ini adalah pergerakan sosial transnasional dari S. Tarrow yang berfokus pada empat karakteristik yaitu kesempatan politik, struktur mobilisasi, kerangka tindakan kolektif, serta repertoar perlawanan. Dari hasil penelusuran artikel ini, diketahui kampanye Anonymous melawan jaringan teroris transnasional terdiri dari enam operasi yang dilakukan selama periode 2015-2016. Operasi tersebut dilakukan oleh enam kelompok peretas sebagai bagian dari Anonymous terhadap Al-Qaeda in the Arabian Peninsula (AQAP) dan Islamic State of Iraq and Syria (ISIS) sebagai targetnya. Artikel ini menemukan Anonymous melakukan empat karakteristik pergerakan sosial transnasional dari S. Tarrow dalam enam kampanye terhadap jaringan teroris transnasional. Lebih lanjut, terdapat ciri khas tersendiri dari Anonymous sebagai aktor pergerakan sosial transnasional. 


\section{Pendahuluan}

Dalam

diplomasi,

hukum

internasional, komunikasi media, dan analisis akademik sudah secara luas hubungan internasional dinyatakan terdiri dari hubungan yang dilakukan antara unit yang koheren bernama negara, Namun, aktor dalam hubungan internasional tidak hanya negara saja. Terdapat aktor-aktor yang lain juga seperti organisasi internasional antarpemerintah, organisasi internasional non-pemerintah, perusahaan multinasional, serta jaringan transnasional. ${ }^{1}$

Anonymous merupakan hacktivist dari berbagai negara yang secara bebas beroperasi tetapi dipersatukan dengan paham yang sama. Komunitas peretas ini dikenal oleh berbagai serangan siber terhadap jaringan sistem komputer atau situs daring. Berbagai aksi tersebut adalah respon perlawanan mereka terhadap pihak tertentu seperti pemerintah, korporasi, atau organisasi yang terkait dengan isu-isu yang dipertentangkan. Contohnya sensor dan privasi dalam ruang siber. Penampilan publik dari anggota Anonymous sering dikaitkan dengan penggunaan topeng Guy Fawkes. Topeng tersebut mereferensikan protagonis film $V$ for Vendetta. $^{2}$

Dalam media massa, Anonymous sering diberitakan mengklaim atau ditemukan bertanggung jawab atas terjadinya serangan siber terhadap target tertentu. Aksi pertama dari Anonymous yang mendunia adalah serangan siber terhadap Church of Scientology pada tahun 2008 untuk memprotes praktik religius mereka. Di 2010, Anonymous melakukan serangan siber terhadap pemerintah Amerika Serikat sebagai bentuk dukungan mereka terhadap pemilik situs WikiLeaks

\footnotetext{
${ }^{1}$ P. Willetts, "Transnational Actors and International Organizations in Global Politics," dalam The Globalization of World Politics: An Introduction to International Relations, ed. J. Baylis, S. Smith, \& P. Owens (New York: Oxford University Press, 2014), 321.

${ }^{2}$ P. J. Springer, Cyber Warfare: A Reference Handbook (Santa Barbara: ABC-CLIO, 2015).
}

yaitu Julian Assange yang memublikasikan informasi sensitif milik Amerika Serikat. Kemudian, Anonymous juga terlibat dalam pergerakan Arab Spring dengan melakukan serangan siber terhadap situs pemerintah Tunisia dan Mesir pada tahun 2011.

Pada tahun 2015, Anonymous diberitakan mengadakan kampanye untuk melakukan aksi peretasan atau serangan siber terhadap jaringan teroris. Kampanye tersebut diumumkan dengan video dan pesan melalui akun media sosial milik mereka. Anonymous menyatakan ajakan berpartisipasi dalam "perang siber total" sebagai respon untuk melawan segala aksi yang pernah dilakukan oleh teroris. Kemudian, Anonymous menyatakan juga tidak akan pernah berhenti untuk tetap melakukan perlawanan terhadap jaringan teroris hingga mereka lenyap. ${ }^{4}$

\footnotetext{
${ }^{3}$ P. Shakarian, J. Shakarian, dan A. Ruef, Introduction to Cyber-Warfare: A Multidisciplinary Approach (Waltham: Syngress, 2013).

${ }^{4}$ A. Hern, "Anonymous 'at war' with Isis, hacktivist group confirms," The Guardian, https://www.theguardian.com/technology/2015/nov/ 17/anonymous-war-isis-hacktivist-group-confirms (diakses 12 Juni 2019.; T. John, "Anonymous Launches 'Biggest Operation' Against ISIS in Response to Paris Attacks," TIME, http://time.com/4114182/anonymous-paris-attacks/ (diakses 12 Juni 2019); C. Perez, "Anonymous attacks ISIS supporters online," New York Post, https://nypost.com/2015/02/10/hacking-groupanonymous-attacks-isis-supporters-online/ (diakses 12 Juni 2019); D. Reinsigner, "Anonymous Declares Cyber War on ISIS. Why It Matters," Fortune, http://fortune.com/2015/11/16/anonymous-cyberwar-isis/ (diakses 12 Juni 2019); K. Rogers,

"Anonymous Hacker Fight ISIS but Reactions Are Mixed," The New York Times, https://www.nytimes.com/ 2015/11/26/world/europe/anonymous-hackers-fightisis-but-reactions-are-mixed.html (diakses 12 Juni 2019); C. Zakrewski, "Hacking Collective Anonymous Declare Total War On ISIS Following Paris Terror Attacks," Tech Crunch, https://techcrunch.com/2015/11/16/hackingcollective-anonymous-declares-total-war-on-isisfollowing-paris-terror-attacks/ (diakses 12 Juni 2019). Berdasarkan pemberitaan daring yang dimuat oleh media massa tersebut.
} 
Muhammad Fikry Anshori | Hacktivist pada Pergerakan Sosial Transnasional: Kampanye Anonymous melawan Jaringan Teroris Transnasional 2015-2016

Dari paparan pada bagian sebelumnya, kampanye Anonymous melawan jaringan teroris merupakan fenomena pergerakan sosial transnasional yang perlu untuk dibahas karena dilakukan oleh jaringan transnasional berupa hacktivist terhadap jaringan transnasional lainnya yaitu teroris. Hal ini berbeda dengan pergerakan sosial transnasional oleh hacktivist pada umumnya yang menjadikan negara, perusahaan multinasional, dan organisasi internasional antarpemerintah sebagai targetnya. ${ }^{5}$

Oleh karena itu, artikel ini mengajukan pertanyaan berupa bagaimana karakteristik pergerakan sosial transnasional dalam kampanye Anonymous melawan jaringan teroris? Dengan pernyataan tersebut, artikel ini bertujuan untuk mendeskripsikan karakteristik pergerakan sosial transnasional dalam aktivitas kampanye Anonymous melawan jaringan teroris transnasional.

\section{Metode Penelitian}

Metode yang digunakan dalam artikel ini adalah deskriptif kualitatif. Metode tersebut digunakan karena sesuai

\footnotetext{
${ }^{5}$ C. Delmas, "Is Hacktivism The New Civil Disobedience?," Raisons Politiques, no 69 (2018): 63-81; M.B. Machado, "Between control and hacker activism:the political actions of Anonymous Brasil," História, Ciências, Saúde - Manguinhos 22, (2015): 1-18; G. Mikhaylova, "The "Anonymous"

Movement: Hacktivism as An Emerging of Political Participation" (Master Thesis, Texas State University, 2014); W. S. Pendegrass, "What is Anonymous?: A Case Study of An Information Systems Hacker Activist Collective Movement" (Doctoral dissertation, Robert Morris University, 2013); A. W. Samuel, "Hacktivism and the Future of Political Participation" (PhD dissertation, Harvard University, 2004); T. Sorell, "Human Rights and Hacktivism: The Cases of Wikileaks and Anonymous," Journal of Human Rights Practice 7, no. 3 (2015): 391-410; J. M. Wright, "Digital Contention: Anonymous and the Freedom of Information Movement" (Master thesis, Purdue University, 2012). Berdasarkan penelitian terdahulu tersebut.
} dengan tujuan penulisan dari artikel ini. Teknik pengumpulan data yang digunakan adalah studi berbasis internet dan studi berbasis pustaka. Data yang dikumpulkan terdiri dari dua tema. Tema data pertama adalah aktivitas kampanye Anonymous melawan jaringan teroris transnasional. Tema data kedua adalah karakteristik kampanye Anonymous melawan jaringan teroris transnasional. Setalah data dikumpulkan dan valid, data disajikan dengan visualisasi atau uraian.

\section{Hasil dan Diskusi \\ Pergerakan Sosial Transnasional dan Hacktivist}

Hubungan transnasional adalah interaksi masyarakat dari setidaknya dua negara yang berbeda dalam cakupan isu spesifik. Setiap interaksi ditentukan oleh pihak non-pemerintah dan dilakukan secara langsung oleh partisipasi masyarakat. ${ }^{6}$ Hubungan transnasional dapat didefinisikan juga sebagai kontak, koalisi, dan interaksi yang melintasi batasan nasional serta tidak dikendalikan oleh organ utama kebijakan luar negeri dari pemerintah. ${ }^{7}$ Definisi lain dari hubungan transnasional adalah interaksi melintasi batasan nasional dengan salah satu aktor adalah non-negara yang berarti tidak beroperasi atas nama pemerintah nasional atau organisasi internasional antarpemerintah. ${ }^{8}$

Istilah transnasional berbeda dengan internasional, multinasional, dan nasional berdasarkan cakupan dari operasi yang berupa partisipasi, interaksi, dan organisasi. Nasional merujuk operasi yang berlangsung

\footnotetext{
${ }^{6}$ K. Kaiser, "Transnational Politics: Toward a Theory of Multinational Politics," International Organization 25, no. 4 (1971): 802.

${ }^{7}$ J. S. Nye Jr. dan R. O. Keohane, "Transnational Relations and World Politics: An Introduction," International Organization 25. No. 3 (1971): 331.

${ }^{8}$ T. Risse-Kappen, "Bringing Transnational Relations Back In: Introduction," dalam Bringing Transnational Relations Back In: Non-State Actors, Domestic Structures an International Institutions, ed. T. Risse-Kappen, (New York: Cambridge University Press, 1995), 3.
} 
dalam wilayah suatu negara saja. Sedangkan transnasional menggambarkan operasi di dua atau lebih negara yang dilakukan tanpa kontrol pemerintah suatu negara. Kemudian, internasional menggambarkan operasi di dua atau lebih negara yang secara dominan dilakukan dengan partisipasi pemerintah suatu negara. Terakhir, multinasional menggambarkan operasi yang melibatkan warga dari dua atau lebih negara yang berbeda. ${ }^{9}$

Dalam hubungan transnasional, terdapat kumpulan aktor yang saling berinteraksi tanpa keberadaan otoritas terpusat untuk mengelola mereka. Hal tersebut disebut jaringan. $^{10}$ Jaringan transnasional mencakup berbagai macam partisipasi aktor secara longgar yang saling berbagi nilai, kepercayaan, prinsip, dan wacana bersama. Jenis jaringan transnasional antara lain adalah komunitas epistemik yang berbasiskan keilmuan, koalisi transnasional sebagai koordinator strategi perubahan sosial masyarakat, jaringan advokasi transnasional, serta pergerakan sosial transnasional. ${ }^{11}$

Pergerakan sosial adalah keterlibatan kelompok yang dimobilisasi secara sosial dalam perlawanan terhadap pemangku kekuasaan (powerholders). Ada dua posisi aktor dalam pergerakan sosial yaitu target dan partisipan. ${ }^{12}$ Dari definisi tersebut, pergerakan sosial transnasional dapat didefinisikan sebagai keterlibatan kelompok yang dimobilisasi secara sosial yang partisipannya berasal dari dua atau lebih negara berbeda dalam interaksi

\footnotetext{
${ }^{9}$ S. P. Huntington, "Transnational Organizations in World Politics," World Politics 25, no. 3, (1973): 335-336.

${ }^{10}$ J. M. Podolny dan K. L. Page, "Network Forms of Organization," Annual Review of Sociology, vol. 24, (1998): 59.

${ }^{11}$ T. Risse, "Transnational Actors and World Politics," dalam Handbook of International Relations, W. Carlsnaes, T. Risse, dan B. A. Simmons, (London: SAGE, 2013), 427-428. ${ }^{12}$ D. McAdam, S. Tarrow, dan C. Tilly, Dynamics of Contention, (New York: Cambridge University Press, 2001).
}

perlawanan yang berkelanjutan terhadap pemerintah suatu negara, institusi internasional, atau aktor multinasional. Lebih lanjut, sesuatu dikatakan sebagai pergerakan sosial transnasional ketika memiliki basis di masyarakat dari negara yang berbeda-beda serta terlibat dalam interaksi perlawanan yang berkelanjutan. ${ }^{13}$ Pergerakan sosial transnasional memiliki empat macam karakteristik: (1) kesempatan politik (political opportunities), (2) struktur mobilisasi (mobilizing structures), (3) kerangka tindakan kolektif (collective action frame), dan (4) repertoar perlawanan (repertoires of contention). ${ }^{14}$

Pertama, kesempatan politik adalah struktur politik statis yang kemudian mengalami perubahan lingkungan secara politis. Kemudian, struktur mobilisasi adalah bentuk dari pergerakan yang berupa organisasi berstruktur formal atau jaringan sosial longgar. Selanjutnya, kerangka tindakan kolektif merupakan pembingkaian terhadap orientasi bentuk partisipasi secara tetap atau berubah. Terakhir, repertoar perlawanan merupakan respon terhadap perkembangan pergerakan dan perubahan dari pihak yang dilawan. ${ }^{15}$

Pergerakan sosial transnasional dimulai dengan munculnya kesempatan politik terlebih dahulu. Hal ini adalah kunci pergerakan sosial. Kesempatan politik mendorong masyarakat untuk melakukan atau tidak melakukan tindakan perlawanan kolektif. Acuan bagi kesempatan politik adalah konsistensi dalam lingkungan politik. Ketika lingkungan politik yang awalnya statis dan konsisten tersebut mengalami perubahan kondisi luar biasa

\footnotetext{
${ }^{13}$ S. Tarrow, "Transnational Politics: Contention and Institution in International Politics," Annual Review of Political Science, vol. 4, (2001): 11.

${ }^{14} \mathrm{~S}$. Tarrow, The New Transnational Activism, (New York: Cambridge University Press, 2005). ${ }^{15}$ Ibid.
} 
yang perlu dilawan maka pergerakan sosial baru terjadi. ${ }^{16}$

Aktor dalam pergerakan sosial transnasional disebut sebagai aktivis (activist). Pada saat ini terdapat berbagai jenis aktivis yang dalam melakukan aksinya didukung oleh keberadaan teknologi informasi dan komunikasi (TIK). Salah satu dari jenis aktivis tersebut adalah hacktivist. ${ }^{17}$

Istilah hacktivist merupakan kombinasi dari dua kata yaitu retas (hack) dan aktivis. Salah satu definisi dari hacktivist adalah individu atau kelompok yang melakukan aksi peretasan dengan tujuan atau motivasi yang bersifat politis. ${ }^{18}$ Selain itu, hacktivist dapat didefinisikan juga sebagai kelompok atau individu yang melakukan serangan siber (cyberattack) dengan motivasi yang bersifat politis untuk menyebarkan paham atau pesan politik tertentu. $^{19}$ Istilah peretasan merupakan kegiatan eksploitasi kerentanan sistem jaringan komputer. ${ }^{20}$ Sedangkan serangan siber adalah tindak ofensif yang merusak dengan sistem jaringan komputer sebagai targetnya. ${ }^{21}$

\footnotetext{
${ }^{16}$ S. Tarrow, Power in Movement: Social Movements and Contentious Politics, (New York: Cambridge University Press, 2011).

${ }^{17}$ J. J. George dan D. E. Leidner, "From Clicktivism to Hacktivism: Understanding Digital Activism," Information and Organization, https://doi.org/ 10.1016/j.infoandorg.2019.04.001 (diakses 12 Juni 2019).

${ }^{18}$ P. W. Singer dan A. Friedman, Cybersecurity and Cyberwar: What Everyone Needs to Know, (New

York: Oxford University Press, 2014).

${ }^{19}$ D. S. Reveron, "An Introduction to National Security and Cyberspace," dalam Cyberspace and National Security: Threats, Opportunities and Power in a Virtual World, ed. D. S. Reveron, (Washington D.C.: Georgetown University Press, 2012), 12.

${ }^{20}$ I. Bernik, Cybercrime and Cyberwarfare, (London: ISTE, 2014).

${ }^{21}$ R. B. Hughes, "How is the Cyber Revolution Changing Asia-Pacific National Security Concerns?," dalam Asia-Pacific Security: An Introduction, dalam J. Wallis dan A. Carr, (Washington DC: Georgetown University Press, 2016), 203.
}

Keberadaan hacktivist tidak lepas dari perkembangan komunitas peretas (hacker community). Komunitas peretas awalnya kumpulan individu yang bereksperimen terhadap perangkat keras (hardware) dan perangkat lunak (software) komputer di tahun 1970-an. Pada tahun 1980-an, istilah komunitas peretas mulai dikenal sebagai kumpulan individu yang melakukan kegiatan pembobolan yang merusak terhadap jaringan sistem komputer dengan teknik tertentu secara daring. Kegiatan meretas mereka hanya bertujuan untuk mengambil keuntungan ekonomi atau menunjukan keunggulan penggunaan teknologi. Komunitas peretas yang melakukan aktivitasnya atas dasar politik baru mulai muncul pada pertengahan tahun 1990-an. ${ }^{22}$

Motivasi hacktivist untuk melakukan aksinya dapat berupa pandangan politik, kesukuan atau etnis, kepercayaan atau agama, rasa bangga terhadap negara, dan ideologi tertentu. Beberapa contohnya adalah anarkisme, patriotisme, nasionalisme, maupun terorisme. Kemudian, motivasi dari hacktivist dapat juga berdasarkan topik atau isu tertentu yang sedang dipertentangkan di tengah masyarakat dalam lingkup nasional atau global. Seperti misalnya kebebasan berpendapat dan berkelompok, hak warga sipil, hak etnis atau suku minoritas, serta hak memeluk kepercayaan atau agama tertentu. Hampir berbagai macam isu atau ideologi terdapat pendukung yang merupakan hacktivist. ${ }^{23}$

Hacktivist memiliki tiga sumber kekuatan relatif untuk dapat melakukan aksinya. Pertama, partisipasi menjadi hacktivist memerlukan dana yang cukup rendah. Hal utama yang diperlukan oleh hacktivist adalah komputer dan internet.

\footnotetext{
${ }^{22}$ T. Jordan dan P. A. Taylor, Hacktivism and Cyberwars: Rebels with a Cause?, (London: Routledge, 2004).

${ }^{23}$ J. Andreas dan S. Winterfeld, Cyber Warfare:

Techniques, Tactics and Tools for Security

Practitioners, (Waltham: Syngress, 2014).
} 
Kedua, hacktivist memiliki anonimitas virtual dalam ruang siber. Kekuatan relatif ini memungkinkan hacktivist untuk tidak terdeteksi dalam waktu yang cukup lama. Ketiga, hacktivist memiliki kerentanan yang asimetris dari serangan siber. Dengan struktur hacktivist yang longgar maka kemungkinan mereka terkena serangan siber lebih kecil dibandingkan organisasi dengan struktur kokoh seperti pemerintah atau korporasi. ${ }^{24}$

Teknik yang digunakan hacktivist dalam melakukan aksinya berupa penggunaan perangkat lunak dengan kemampuan untuk melakukan peretasan yang dibuat secara mandiri atau pihak ketiga. Perangkat lunak tersebut dapat dibagi menjadi beberapa jenis berdasarkan fungsinya yaitu pengintaian (reconnaissance), pemindaian (scanning), dan penyerangan (attack). Pengintaian adalah pengumpulan informasi umum dari target. Pemindaian adalah pengumpulan informasi kerentanan target. Penyerangan adalah eksploitasi kerentanan target. ${ }^{25}$

Contoh perangkat lunak yang digunakan oleh hacktivist dalam melakukan aksinya adalah WHOIS Search, DNS Queries Nmap, Nessus, Open VAS, Metasploit, Denial of Services, dan Malicious Software (Malware). ${ }^{26}$

\section{Aktivitas dan Karakteristik Kampanye Anonymous melawan Jaringan Teroris Transnasional}

Secara umum, kampanye

Anonymous melawan jaringan teroris transnasional dilakukan oleh kelompok yang beroperasi mandiri dan menyatakan diri sebagai bagian dari Anonymous. Kelompok ini terdiri dari peretas yang dengan sukarela berpartisipasi atas dasar

\footnotetext{
${ }^{24}$ J. S. Nye Jr., The Future of Power, (New York: Public Affairs, 2011).

${ }^{25}$ S. Winterfeld dan J. Andreas, The Basic of Cyber Warfare: Understanding the Fundamentals of Cyber Warfare in Theory and Practice, (Waltham:

Syngress, 2013).

${ }^{26}$ Ibid.
}

kesamaan tujuan yaitu memusnahkan teroris secara daring. Kelompok-kelompok tersebut adalah Ghost Security (GhostSec), BinarySec, VandaSec, CtrlSec, Anonymous Wolf Security (WolfSec), dan WauchulaGhost. Berikut adalah profil mereka.

GhostSec adalah kelompok peretas yang memiliki tujuan menanggulangi terorisme dan melawan paham radikal di ruang siber. Aksi yang dilakukan oleh GhostSec adalah pencarian dan pengintaian, pengumpulan data yang mengancam, penyebaran kesadaran situasi, investigasi lanjutan, serta penyerangan strategis terkendali. ${ }^{27}$ Kapasitas yang dimiliki oleh GhostSec untuk melawan jaringan teroris bersifat ofensif dan juga defensif. Aksi yang mereka lakukan didukung dengan mahadata (big data) terkait teroris. ${ }^{28}$ Selain itu, GhostSec juga menghadirkan berbagai layanan bagi pihak ketiga jika tujuannya adalah melawan teroris. $^{29}$

BinarySec adalah kelompok yang berpartisipasi dalam kampanye melawan jaringan teroris transnasional dengan cara meretas berbagai akun media sosial dan situs daring yang melakukan propaganda paham teroris, aksi teroris, serta perekrutan anggota teroris. ${ }^{30}$ Anggota BinarySec mempunyai latar belakang dan kecakapan peretasan yang berbeda-beda. Dalam

\footnotetext{
${ }^{27}$ Ghost Security Group, “About,” Ghost Security Group, https://ghostsecuritygroup.com/about-ghostsecurity-group/ (diakses 12 Juni 2019).

${ }^{28}$ Oracle, "What is Big Data?," Oracle, https://www.oracle.com/big-data/guide/what-is-bigdata.html (diakses 14 Juni 2019). Big data adalah sekumpulan informasi bernilai dalam ukuran yang besar, diperoleh dengan cepat, dan bersifat kompleks.

${ }^{29}$ Ghost Security Group, "Capabilities," Ghost Security Group, https:/ghostsecuritygroup.com/ghost-securitygroup-capabilities/ (diakses 12 Juni 2019).

${ }^{30}$ CyberDB, "BinarySec," CyberDB: The Cyber Research Databank, https://www.cyberdb.co/vendor/ binarysec/ (diakses 12 Juni 2019).
} 
melakukan aksinya, setiap anggota terlebih dahulu memastikan akun media sosial dan situs daring yang diserang berafiliasi dengan teroris. Kemudian, mereka akan menyerang akun media sosial dan situs daring teroris agar tidak dapat aktif lagi. ${ }^{31}$

VandaSec merupakan kelompok peretas yang melakukan identifikasi terhadap Internet Protocol Address (IP Address) milik jaringan teroris maupun warganet yang mendukung aktivitas teroris. $^{32}$ Mereka melakukan identifikasi dengan pelacakan perpindahan data yang mencurigakan antar komputer. Teknik tersebut dapat mengidentifikasi lokasi komputer yang mengirimkan data mencurigakan tersebut. Dari hasil identifikasi, VandaSec dapat menduga juga domisili dari warganet yang bisa jadi berafiliasi atau mendukung aktivitas teroris. Implikasinya, informasi tersebut dapat digunakan untuk memprediksi aktivitas jaringan teroris di dunia nyata. ${ }^{33}$

CtrlSec adalah kelompok yang melakukan aksi peretasan terhadap akun media sosial Twitter dari warganet yang mendukung aktivitas teroris. Seperti menyebarkan propaganda aksi teror dan pengumuman perekrutan anggota jaringan teroris secara daring. CtrlSec melakukan identifikasi berbagai macam akun Twitter

\footnotetext{
${ }^{31}$ P. Paganini, "Hacker Interviews - The Riddler, the founder of the BinarySec Group," Security Affairs,

https://securityaffairs.co/wordpress/50886/hacking/ hacker-interviews-binarysec.html (diakses 12 Juni 2019).

32 Techopedia, "Internet Protocol Address (IP Address)," Techopedia, https://www.techopedia.com/ definition/2435/internet-protocol-address-ip-address (diakses 14 Juni 2019). IP Address adalah deretan angka untuk menandai perangkat keras, seperti komputer, dalam jaringan.

${ }^{33}$ P. Paganini, "A group of hackers known as VandaSec claims three ISIS Twitter accounts trace back to computers belonging to the UK government," Security Affairs, https://securityaffairs.co/wordpress/ 42881/hacking/isis-twitter-linked-uk-govt.html (diakses 12 Juni 2019).
}

pendukung teroris. Mereka akan menyerang akun Twitter pendukung teroris secara daring sehingga tidak dapat lagi aktif. Selain itu, CtrlSec menyediakan juga situs daring bernama Report Online Terrorism sebagai wadah untuk melaporkan akun Twitter yang dicurigai milik teroris. $^{34}$

WolfSec adalah kelompok peretas yang terdiri dari partisipan aksi Anonymous di masa lalu. Operasi tersebut seperti OpInfiltrate pada tahun 2012, OpHailStorm pada tahun 2013, dan OpUnite pada tahun 2014. Sebagai bagian dari Anonymous, WolfSec juga memegang nilai dan prinsip dari Anonymous. Contohnya adalah tidak memiliki ketua dan tidak akan menyerang pihak-pihak yang melakukan penindasan terhadap pihak tertentu. Dalam praktiknya, WolfSec melakukan aksi peretasan terhadap target tertentu secara reaktif dan periodik. ${ }^{35}$ WauchulaGhost merupakan kelompok yang berpartisipasi dalam aksi peretasan dengan keyakinan berupa teroris adalah pihak yang harus dilawan. ${ }^{36}$ WauchulaGhost menjalankan aksi peretasan yang unik untuk melawan teroris. Seperti meretas akun media sosial milik anggota jaringan teroris untuk menampilkan kiriman konten pornografi atau mengubah gambar profil akun media sosial teroris dengan logo pelangi dari Lesbian, Gay, Bisexual, and Transgender (LGBT). Tujuan dari aksi tersebut untuk mengubah citra warganet terhadap keberadaan akun media sosial yang berafiliasi dengan teroris. ${ }^{37}$

\footnotetext{
${ }^{34}$ CtrlSec, "CtrlSec," Twitter, https://twitter.com/ CtrlSec (diakses 12 Juni 2019); CtrlSec, "Report Online Terrorism," Report Online Terrorism, http://reportonlineterrorism.com/ (diakses 12 Juni 2019).

${ }^{35}$ Anonymous WolfSec, “About," Facebook, https://www.facebook.com/pg/WolfSecurities/about / (diakses 12 Juni 2019).

36 WauchulaGhost, "About the Ghost," WauchulaGhost: The Ghost of No Nation, https://wauchulaghost.com/about/ (diakses 12 Juni 2019).

${ }^{37}$ L. Segall, "Meet the hacker fighting ISIS with porn," CNN, https://money.cnn.com/2016/06/16/
} 
Pihak yang dijadikan target oleh Anonymous dalam kampanye melawan jaringan teroris transnasional adalah teroris yang pernah beroperasi di dua atau lebih negara berbeda. Jaringan teroris tersebut adalah Al-Qaeda in the Arabian Peninsula (AQAP) dan Islamic State of Iraq and Syria (ISIS). Berikut adalah profil mereka. AQAP adalah jaringan teroris yang dibentuk pada tahun 2009. Beberapa tokoh pendiri AQAP adalah Nasir Al-Wuhayshi, Said Al-Shihri, Qasim Al-Raymi, dan Mohamad Al-Afwi. Pemikiran yang diusung oleh AQAP sebagai fondasi politik adalah Sunni, Jihadisme, Salafi, dan Takfiri. $^{38}$ Tujuan utama AQAP adalah membentuk pemerintahan di Semenanjung Arab yang menegakkan hukum Syariah sepenuhnya. $^{39}$ Tujuan tersebut dicapai dengan melakukan aksi teror seperti penembakan atau pengeboman terhadap publik. Kawasan yang menjadi area operasi AQAP di antaranya adalah Timur-Tengah,

technology/isis-hacker-porn-gay-pride/index.html (diakses 12 Juni 2019).

${ }^{38}$ J. L. Esposito, "Sunni Islam," Oxford Islamic Studies Online,

http://www.oxfordislamicstudies.com/ article/opr/t125/e2280 (diakses 14 Juni 2019). Sunni merupakan pandangan yang mengutamakan AlQuran, ajaran Nabi Muhammad, dan konsensus ulama sebagai pedoman beribadah; J. L. Esposito, "Jihad," Oxford Islamic Studies Online, http://www. oxfordislamicstudies.com/article/opr/t125/e1199 (diakses 14 Juni 2019) Jihadisme merupakan pandangan yang mempromosikan kekerasan terhadap Muslim dan Non-Muslim; J. L. Esposito, "Salafi," Oxford Islamic Studies Online, http://www.

oxfordislamicstudies.com/article/opr/t125/e2072 (diakses 14 Juni 2019). Salafi adalah pergerakan yang menekankan restorasi Islam ke bentuk awal; J.

L. Esposito, "Takfir," Oxford Islamic Studies Online,

http://www.oxfordislamicstudies.com/article/opr/t12 5/e2319 (diakses 14 Juni 2019). Takfiri adalah paham diskriminatif terhadap Non-Muslim.

${ }^{39}$ J. L. Esposito, "Shariah," Oxford Islamic Studies Online,

http://www.oxfordislamicstudies.com/article/ opr/t125/e2168 (diakses 14 Juni 2019). Hukum Islamik yang berpedoman pada Al-Quran dan ajaran Nabi Muhammad.
Asia Selatan, Asia Tenggara, Eropa, dan Amerika Utara. ${ }^{40}$

ISIS merupakan jaringan teroris yang didirikan oleh Abu Musab Al-Zarqawi dan Abu Bakr Al-Baghdadi pada tahun 2013. Dasar motivasi politik dari ISIS adalah ideologi Jihadisme, Pan-Islamisme, Salafi, dan Takfiri. $^{41}$ Tujuan ISIS adalah membentuk negara Islam yang menegakkan hukum Syariah seperti masyarakat muslim pada masa lalu. Aksi yang dilakukan oleh ISIS adalah teror terhadap publik dengan pembunuhan, penyanderaan, dan pengeboman. Basis operasi ISIS di negara Iraq dan Syria. Kawasan yang dijadikan target mereka adalah Timur-Tengah, Afrika Utara, Asia Selatan, Asia Tenggara, dan Eropa. ${ }^{42}$

Kampanye yang dilakukan oleh kelompok Anonymous untuk melawan jaringan teroris dilakukan dalam beberapa operasi. Operasi yang dilakukan bersifat reaktif, intensif, dan periodik. Secara umum, terdapat enam operasi yang

\footnotetext{
${ }^{40}$ CFR Staff, "Al-Qaeda in the Arabian Peninsula (AQAP)," Council on Foreign Relations, https://www.cfr.org/backgrounder/al-qaeda-arabianpeninsula-aqap (diakses 12 Juni 2019); CNN Library, "AQAP Fast Facts," CNN, https://edition.cnn.com/ 2015/06/16/middleeast/aqap-fast-facts/index.html (diakses 12 Juni 2019); Counter Extremist Project, "Al-Qaeda in the Arabian Peninsula (AQAP)," Counter Extremist Project, https://www. counterextremism.com/threat/al-qaeda-arabianpeninsula-aqap (diakses 12 Juni 2019).

${ }^{41}$ J. L. Esposito, "Pan-Islamism," Oxford Islamic Studies Online, http://www.oxfordislamicstudies.com/ article/opr/t125/e1819 (diakses 14 Juni 2019). PanIslamisme merupakan ideologi yang mempromosikan solidaritas Muslim transnasional. ${ }^{42}$ CNN Library, "ISIS Fast Facts," CNN, https://edition.cnn.com/2014/08/08/world/isis-fastfacts/index.html (diakses 12 Juni 2019); Counter Extremist Project, "ISIS,", Counter Extremist Project, https://www.counterextremism.com/threat/isis (diakses 12 Juni 2019); Z. Laub, "The Islamic State," Council on Foreign Relations, https://www.cfr.org/ backgrounder/islamic-state (diakses 12 Juni 2019).
} 
dijalankan oleh mereka dalam kurun waktu 2015 hingga 2016. Operasi tersebut adalah 1) OpCharlieHebdo, 2) OpISIS, 3) OpParis, 4) Daeshbags,5) OpBrussels, dan 6) OpNice. Berikut adalah informasi ringkas setiap operasi.

OpCharlie Hebdo merupakan respon Anonymous terhadap penyerangan kantor majalah Charlie Hebdo di Paris, Perancis pada Januari 2015. Penyerangan tersebut berupa penembakan yang menewaskan 12 orang termasuk editor, jurnalis, dan kartunis dari Charlie Hebdo serta polisi wanita. Pelaku penembakan berjumlah tiga orang yang berafiliasi dengan AQAP. Kejadian ini memunculkan respon kecaman terhadap AQAP dari berbagai pihak. ${ }^{43}$ Dalam video dan rilis pers, Anonymous menyatakan penyerangan Charlie Hebdo mencederai kebebasan berpendapat (freedom of speech). Bagi Anonymous, menyerang kebebasan berpendapat berarti menyerang juga Anonymous. Berbagai pihak yang berafiliasi dengan teroris tersebut akan mendapatkan serangan siber yang masif dari Anonymous. Anonymous juga mengajak untuk warga di dunia agar tidak diam dan ikut terlibat juga dalam OpCharlieHebdo. ${ }^{44}$ Operasi ini mencari dan mengidentifikasi berbagai akun media sosial orang yang berafiliasi dengan AQAP. Anonymous mengajak warganet untuk melaporkan temuan terkait hal tersebut melalui media sosial dengan tagar \#OpCharlieHebdo.

\footnotetext{
${ }^{43}$ BBC, "As It Happened: Charlie Hebdo Attack," $B B C$, https://www.bbc.com/news/live/world-europe30710777 (diakses 24 Juni 2019); BBC, "Charlie Hebdo Attack: Three Days of Terror,” $B B C$, https://www.bbc.com/news/world-europe-30708237 (diakses 24 Juni 2019).

${ }^{44}$ Anonymous, "Anonymous Operation « Charlie Hebdo » \# Anonymous Operations," Anonymous, https://www.anonymous-france.eu/anonymousoperation-charlie-hebdo.html (diakses 24 Juni 2019); Anonymous France, "[ENG] Anonymous \#OpCharlieHebdo," YouTube, https://www.youtube. com/watch? $\mathrm{v}=$ oqbwqmb8P00 (diakses 24 Juni 2019).
}

Pada perkembangannya, operasi ini berhasil menemukan dan mengidentifikasi akun media sosial dari perekrut anggota teroris. Akun tersebut kemudian diretas agar menjadi non-aktif. ${ }^{45}$

OpISIS adalah perluasan dari OpCharlieHebdo. Keberadaan jaringan teroris bagi Anonymous merupakan ancaman kebebasan berpendapat. Ditambah lagi, ISIS melakukan penyiksaan terhadap warga Iraq dan Syria untuk dijadikan sebagai bagian dari mereka. Selain itu, ISIS juga melakukan perekrutan anggota dalam mendukung aksi teror mereka di berbagai negara. $^{46}$ Sosialisasi OpISIS dilakukan dengan video yang disebarkan melalui situs daring. Dalam video tersebut, Anonymous menyatakan mereka adalah Muslim, Nasrani, dan Yahudi dengan profesi dan okupasi beragam dari berbagai ras, etnis, dan negara yang berbeda. Anonymous menyatakan ISIS yang mengklaim dirinya sebagai negara Islam bukan Muslim sebenarnya. Kemudian, Anonymous menyatakan mereka akan memburu dan menumpas ISIS secara daring. ${ }^{47}$ Pada operasi ini, mulai terbentuk kelompokkelompok peretas baru. Hal tersebut terjadi karena perkembangan sarana yang dapat melibatkan warganet untuk berpartisipasi. Seperti panduan untuk melakukan aksi peretasan dan situs pelaporan akun media sosial yang dicurigai milik teroris. Dalam operasi ini, Anonymous berhasil

\footnotetext{
${ }^{45}$ A GUEST, "\#OPCHARLIEHEBDO," Pastebin, https://pastebin.com/uzaDjcmu (diakses 24 Juni 2019).

${ }^{46}$ Anonymous, "We are on the side of the oppressed \# Anonymous Operations," Anonymous, https://www. anonymous-france.eu/we-are-on-theside-of-the-oppressed.html (diakses 24 Juni 2019); P. Paganini, "Anonymous launches the OpISIS and brings down ISIS social media accounts," Security Affairs, https://securityaffairs.co/wordpress/33288/hacking/ anonymous-launches-opisis.html (diakses 24 Juni 2019).

${ }^{47}$ M. Houl, "Anonymous- \#OpISIS Continues... Round 2.," YouTube, https://www.youtube.com/ watch?v=BPE_sRhZp6M (diakses 24 Juni 2019).
} 
memusnahkan dua ribu akun media sosial teroris dan mematikan situs media sosial 5elafabook buatan ISIS. ${ }^{48}$

Operasi OpParis dilakukan karena serangan Paris pada November 2015. Pelaku serangan berjumlah sepuluh orang yang berafiliasi dengan ISIS. Serangan dilakukan dengan aksi penembakan dan pengeboman terhadap warga sipil di beberapa lokasi seperti stadion sepak bola, restoran, bar, taman, dan gedung pertunjukan. Aksi teror ini merenggut nyawa 130 orang. ${ }^{49}$ Anonymous menyatakan rasa terkejut dan sedih atas serangan Paris dalam video pers mereka. Kemudian, Anonymous menegaskan keberadaan aksi teror oleh ISIS merupakan pencuri kebebasan setiap individu. Anonymous menambahkan terjadinya serangan oleh teroris jangan membuat diri lemah tetapi memberikan kekuatan. Lebih lanjut, Anonymous mengajak seluruh warga di dunia bersatu untuk mempertahankan kebebasan bersama dengan melakukan perlawanan terhadap ISIS dalam ruang siber. ${ }^{50}$ Anonymous menerbitkan panduan

\footnotetext{
${ }^{48}$ A GUEST, “5elafabook.com,” Pastebin, https://pastebin.com/JdNiMA32 (diakses 24 Juni 2019); Righteous, "OpISIS: A Chronology of Events," AnonHQ, https://anonhq.com/opisis-achronolgy/ (diakses 24 Juni 2019); Vandita, "Anonymous Takes Down ISIS Websites, Confirms Leaked Government Documents Were Real," AnonHQ, https://anonhq.com/anonymous-takes-isiswebsites-confirms-leaked-government-documentsreal/ (diakses 24 Juni 2019).

${ }^{49}$ BBC, "Paris attacks: The investigation so far," $B B C$, https://www.bbc.com/news/world-europe34822265 (diakses 24 Juni 2019); BBC, "Paris attacks: Who were the victims?," $B B C$, https://www.bbc.com/news/world-europe-34821813 (diakses 24 Juni 2019); BBC, "Paris attacks: What happened on the night, " $B B C$,

https://www.bbc.com/news/world-europe-34818994 (diakses 24 Juni 2019).

${ }^{50}$ Anonymous, "Anonymous \#OpParis \# Anonymous Operations," Anonymous, https://www.anonymous-france.eu/anonymousopparis.html (diakses 24 Juni 2019); Anonymous Official, "Anonymous - Operation Paris \#OpParis," YouTube, https://www.youtube.com/ watch?v=ybz59LbbACQ (diakses 24 Juni 2019).
}

untuk mendukung partisipasi warganet dalam OpParis. Panduan aksi perlawanan ISIS tersebut dibagi menjadi tiga jenis yaitu panduan pemula, pelapor, dan pencari. Panduan pemula berisi spesifikasi untuk berpartisipasi. Panduan pelaporan berisi cara mencari, melaporkan, dan meretas akun media sosial teroris. Panduan pencari berisi cara pemetaan jaringan akun media sosial teroris secara daring. ${ }^{5}$

Daeshbags merupakan operasi yang didasari oleh penyiaran video propaganda ISIS di media sosial. Salah satu contohnya adalah video eksekusi jurnalis Amerika Serikat bernama James Foley oleh anggota ISIS di 2014. ${ }^{52}$ Anonymous melihat penyiaran video eksekusi merupakan aksi teror untuk menyebarkan rasa takut kepada khalayak umum. Oleh karena itu, Anonymous meyakini perlu untuk melakukan suatu operasi yang dapat mengubah citra ISIS agar tidak dianggap lagi menakutkan. Operasi tersebut adalah Daeshbags. Daeshbags mengajak warganet untuk membuat meme yang jahil atau jenaka dari gambar anggota ISIS. $^{53}$ Warganet juga diajak untuk mengirimkan kreasi meme mereka melalui akun media sosial masing-masing dengan menyertakan tagar \#OpDaeshbag, \#ISISTrollingDay, atau \#OpTrollISIS. Beberapa contoh kreasi

\footnotetext{
${ }^{51}$ B. Namikaze, "ANONYMOUS RELEASED 3 HOW TO HACK GUIDES AGAINST ISIS," Hacking Dream, https://www.hackingdream.net/ 2015/11/anonymous-released-3-how-to-hackguides.html (diakses 24 Juni 2019); T. Gorton, "Anonymous releases guide on how to hack ISIS," Dazed, https://www.dazeddigital.com/artsandculture/ article/28484/1/anonymous-releases-guide-on-howto-hack-isis (diakses 24 Juni 2019).

${ }^{52}$ C. J. Carter, "Video shows ISIS beheading U.S. journalist James Foley," CNN, https://edition.cnn.com/2014/08/19/world/meast/isis -james-foley/index.html (diakses 24 Juni 2019).

${ }^{53}$ K. Mansfield, “' Expect Us' Anonymous warn ISIS as thousands rally to troll evil terror group TODAY," Express, https://www.express.co.uk/news/world/ 625858/Expect-us-Anonymous-warn-ISISthousands-troll-terrorists (diakses 24 Juni 2019).
} 
Muhammad Fikry Anshori | Hacktivist pada Pergerakan Sosial Transnasional: Kampanye Anonymous melawan Jaringan Teroris Transnasional 2015-2016

meme tersebut antara lain gambar yang mengubah bendera ISIS menjadi bendera yang bertuliskan "We love bacon" (kami suka daging asap babi) (Lihat Gambar 1) serta gambar muka anggota ISIS yang diedit menjadi kepala binatang. Seperti bebek dan babi (Lihat Gambar 2, 3, dan 4). ${ }^{54}$

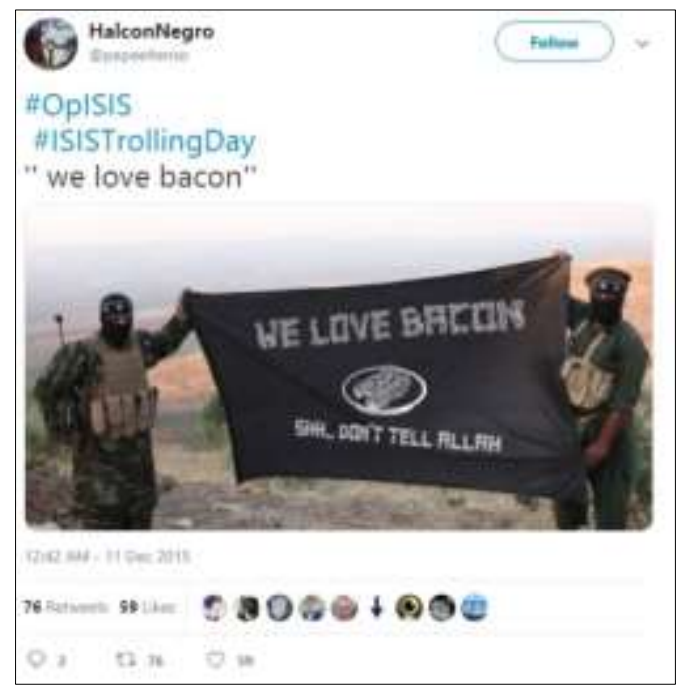

Gambar 1: Meme Bendera ISIS bertuliskan "We Love Bacon"

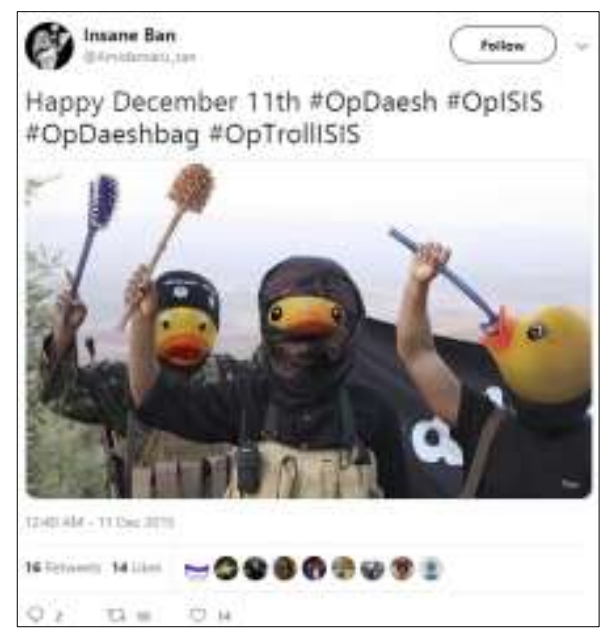

Gambar 2: Meme Beberapa Anggota ISIS berkepala Bebek

\footnotetext{
${ }^{54}$ L. Winchester, "Twitter swamped with images mocking ISIS \#Daeshbags as Anonymous trolling day kicks off," Express, https://www.express.co.uk/news/ world/626003/Islamic-State-Daesh-trolling-dayAnonymous-OpISIS-Daeshbags (diakses 24 Juni 2019).

${ }^{55}$ HalconNegro, "We love bacon," Twitter, https://twitter.com/pepeeltenso/status/67523406973 9909120/photo/1 (diakses 24 Juni 2019).
}

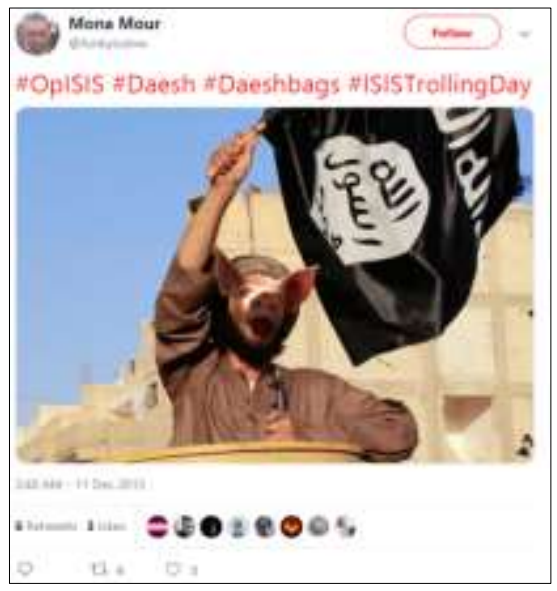

\section{Gambar 3: Meme Seorang Anggota ISIS berkepala Babi ${ }^{56}$}

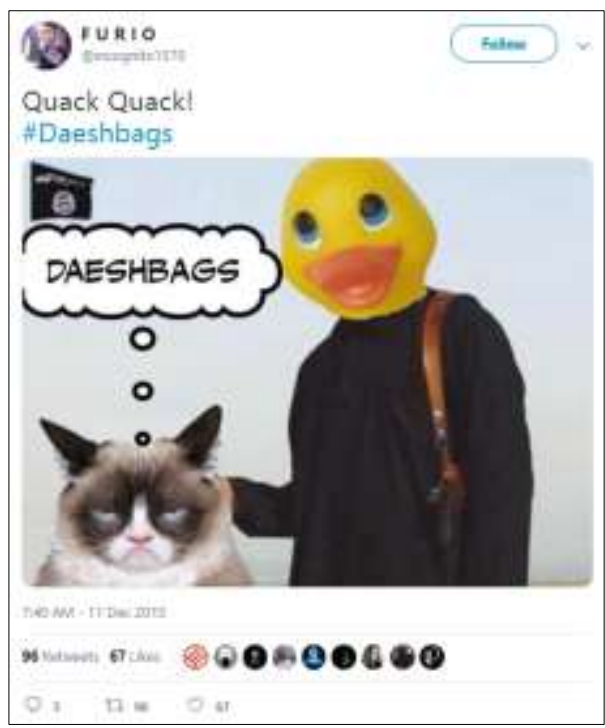

Gambar 4: Meme Seorang Anggota ISIS berkepala Bebek $^{57}$

OpBrussel adalah respon Anonymous terhadap aksi pengeboman di kota Brussel, Belgia pada Maret 2016. Pengeboman terjadi di bandara Zaventem dan stasiun kereta Maelbeek. Pelaku pengeboman adalah lima anggota ISIS. Mereka melakukan aksi terebut karena negara Belgia merupakan partisipan

\footnotetext{
${ }^{56}$ M. Mour, “,” Twitter, https://twitter.com/ funkyoulow/status/675278865028153345/photo/1 (diakses 24 Juni 2019).

${ }^{57}$ FURIO, “Quack Quack!,” Twitter, https://twitter.com/incognito1570/status/675339334 023782400/photo/1 (diakses 24 Juni 2019).
} 
terbesar dalam menyerang ISIS di Iraq dan Syria. Pengeboman tersebut mengakibatkan tewasnya 32 jiwa dan melukai 340 orang. ${ }^{58}$ Anonymous dalam video pers mereka menyebut pengeboman Brussel menegaskan aksi melawan teroris tidak boleh pernah berhenti. Anonymous menyatakan mereka akan melindungi hak kebebasan dan toleransi dengan melacak, menyerang, dan memusnahkan teroris dalam ruang siber. Anonymous juga mengajak warganet berkontribusi dengan setidaknya ikut melacak dan melaporkan informasi keberadaan teroris. Kemudian, Anonymous menyerukan ISIS tidak akan bisa merekrut anggota baru jika Muslim di Eropa diterima menjadi bagian dalam masyarakat dan tidak melakukan diskriminasi. ${ }^{59}$ Pada pelaksanaan operasi OpBrussel, Anonymous mengklaim berhasil mencuri uang dari ISIS. Kemudian, Anonymous melakukan serangan siber terhadap situs daring milik ISIS yang digunakan untuk koordinasi propaganda. Anonymous juga mengklaim berhasil meretas akun media sosial pendukung ISIS. $^{60}$

OpNice merupakan operasi yang dilakukan karena terjadinya aksi teror oleh seseorang yang mengatasnamakan ISIS di Nice, Perancis pada Juli 2016. Aksi

\footnotetext{
${ }^{58}$ BBC, "Brussels explosions: What we know about airport and metro attacks," $B B C$, https://www.bbc. com/news/world-europe-35869985 (diakses 24 Juni 2019); BBC, "Brussels explosions: Why has Belgium's capital been attacked?," $B B C$, https://www.bbc.com/news/world-europe-35870957 (diakses 24 Juni 2019).

59 Anonymous Official, "Anonymous - Operation Brussels \#OpBrussels," YouTube, https://www.youtube.com/watch?v=iJ82nPfWS_k (diakses 24 Juni 2019); Anonymous ArchAngel NetWork Media, "Anonymous \#OpBrussels," YouTube, https://www.youtube.com/watch?v= zBPHbCAo094 (diakses 24 Juni 2019).

${ }^{60}$ P. Paganini, “\#OpBrussells Anonymous 's revenge on ISIS after Brussels attacks," Security Affairs,

https://securityaffairs.co/wordpress/45614/breakingnews/anonymous-opbrussels.html (diakses 24 Juni 2019).
}

tersebut berupa menabrakkan truk kepada kerumunan orang yang sedang meramaikan perayaan Hari Bastille di area Promenade des Anglais. Terjadinya penabrakkan tersebut mengakibatkan timbulnya korban jiwa sebanyak 86 orang dan 303 orang luka-luka. ${ }^{61}$ Dalam video pers, Anonymous menyatakan mereka akan melacak keberadaan anggota teroris yang bertanggung jawab dalam aksi Nice.

Anonymous menegaskan determinasi mereka melawan aksi teroris dengan merujuk berbagai operasi sebelumnya seperti OpParis dan OpBrussel. Lebih lanjut, Anonymous mengajak warganet lainnya untuk melakukan mobilisasi total dalam melacak keberadaan teroris sebagai bentuk perlindungan terhadap nilai kebebasan. ${ }^{62}$ OpNice berlangsung dengan pemusnahan 20.000 akun Twitter yang berafiliasi dengan teroris menjadi tidak aktif. Pemusnahan yang demikian dapat terjadi dengan pelacakan akun media sosial yang menjual budak tawanan dan rampasan artefak dari Iraq dan Syria kepada pembeli potensial. Kegiatan penjualan tersebut merupakan hal yang sedang dilakukan oleh ISIS sebagai dana usaha dalam melakukan aksi teror. $^{63}$

\footnotetext{
${ }^{61}$ BBC, "Nice attack: What we know about the Bastille Day killings," $B B C$, https://www.bbc.com/ news/world-europe-36801671 (diakses 24 Juni 2019); BBC, "Nice attack: Witnesses describe Bastille Day terror," $B B C$,

https://www.bbc.com/news/world-europe-36801431 (diakses 24 Juni 2019).

${ }^{62}$ Anonymous ArchAngel NetWork Media,

"Anonymous \#OpNice," YouTube, https://www. youtube.com/watch? $\mathrm{v}=\mathrm{dQzDEBdo} 4 \mathrm{ck}$ (diakses 24 Juni 2019).

${ }^{63}$ A. Flavio, “Anonymous Vows to Avenge Terror Attack in Nice, Launches \#OpNice to Track Down ISIS Terrorists [Video]," AnonHQ, https://anonhq. com/anonymous-vows-avenge-terror-attack-nicelaunches-opnice-track-isis-terrorists-video/ (diakses 24 Juni 2019); A. Flavio, "New Weapon for Fighting ISIS: Anonymous Attacks Twitter Accounts of Terror Group with Porn," AnonHQ, https://anonhq.com/new-weapon-fighting-isis-
} 
Anonymous melawan Jaringan Teroris Transnasional 2015-2016

Berdasarkan paparan aktivitas kampanye Anonymous melawan jaringan teroris transnasional di atas, dapat diketahui tentang empat karakteristik pergerakan sosial transnasional yang ada dalam kampanye tersebut. Berikut analisis kesempatan politik, struktur mobilisasi, kerangka tindakan kolektif, dan repertoar perlawanan dalam enam operasi yang dilakukan oleh Anonymous dalam melawan AQAP dan ISIS selama 2015-2016.

\section{Aksi yang dilakukan oleh jaringan teroris transnasional merupakan} kesempatan politik yang mendasari operasi Anonymous. Aksi teror yang terjadi dapat mengubah kondisi lingkungan di suatu wilayah. Dari yang awalnya tenang menjadi mencekam dalam waktu yang cepat. Berbagai aksi tersebut terjadi karena motivasi yang bersifat politis dari jaringan teroris transnasional. Jika mencocokkan lini masa aksi teror dengan lini masa kampanye Anonymous maka Kampanye Anonymous selalu terjadi setelah aksi teror di wilayah tertentu. Ditambah lagi, penamaan operasi Anonymous juga mengikuti aksi teror yang terjadi. Contohnya seperti OpCharlieHebdo yang didasari penyerangan kantor majalah Charlie Hebdo serta OpBrussels yang didasari pengeboman kota Brussels. Dengan hal tersebut, dapat dinyatakan operasi Anonymous yang dilakukan untuk melawan jaringan teroris memiliki sifat yang reaktif ketika ada kesempatan politik.

Berdasarkan artikel oleh Brooking dalam Foreign Policy, aksi teror seperti penyerangan Charlie Hebdo merupakan momen ketegangan yang dapat memicu suatu pihak untuk melakukan langkah tertentu. Pada kasus kampanye Anonymous melawan jaringan teroris dapat dinyatakan keberadaan aksi teror menjadi titik awal dalam mengumpulkan partisipan dan membentuk agenda yang dapat mengarahkan pada tindakan perlawanan. Kemudian, khalayak umum juga menjadi

anonymous-attacks-twitter-accounts-terror-groupporn/ (diakses 24 Juni 2019). didorong untuk dapat membangun kecakapan melakukan aksi peretasan agar dapat berpartisipasi pada kampanye melawan keberadaan teroris dalam ruang siber. $^{64}$ Tulisan tersebut menegaskan kesempatan politik merupakan aspek utama dari pergerakan sosial transnasional untuk dapat dimulai dan berkembang. Terbentuknya suasana menegangkan setelah aksi teror merupakan perubahan kondisi lingkungan yang mendorong respon perlawanan. Dapat dinyatakan, Anonymous memanfaatkan momen tersebut sebagai waktu yang tepat untuk inisiasi berbagai operasi dalam kampanye melawan jaringan teroris transnasional.

Struktur mobilisasi sebagai bentuk pergerakan sosial transnasional Anonymous melawan jaringan teroris adalah partisipasi kelompok peretas dan warganet. Keberadaan kelompok peretas menjadi struktur utama yang mendukung berlangsungnya setiap operasi. Hal tersebut terutama karena keberadaan kelompok peretas merupakan partisipan kampanye yang memiliki kecakapan dalam melakukan peretasan dan serangan siber. Kemudian untuk warganet merupakan partisipan yang diajak oleh Anonymous untuk bersamasama melawan jaringan teroris transnasional. Warganet merupakan audiens yang menjadi target sosialisasi informasi tentang operasi yang dilakukan. Dalam hal ini, warganet merupakan partisipan yang bersifat sukarela. Kemudian, mereka belum tentu berpartisipasi dan belum tentu juga memiliki kecakapan dalam meretas. Berdasarkan hal tersebut maka dapat dinyatakan struktur mobilisasi dari kampanye Anonymous melawan jaringan teroris transnasional merupakan jaringan sosial yang memiliki sifat longgar. Aspek yang membuat longgar tersebut antara lain

\footnotetext{
${ }^{64}$ E. T. Brooking, "Anonymous vs. The Islamic State," Foreign Policy, https://foreignpolicy.com/ 2015/11/13/anonymous-hackers-islamic-state-isischan-online-war/ (diakses 2 Juli 2019).
} 
partisipan pergerakan bersifat sukarela, pergerakan dilakukan dengan partisipasi secara mandiri, serta tidak ada struktur formal dalam pelaksanaan pergerakan. Keberadaan setiap aspek tersebut menjadi ciri dari Anonymous itu sendiri.

Berdasarkan artikel oleh Colarik dan Ball dalam Global Security and Intelligence Studies, pelaksanaan pergerakan tidak terlepas dari posisi Anonymous sebagai aktor non-negara dalam ruang siber. Ruang siber memungkinkan sebagai sarana bagi aktor non-negara untuk dapat memberikan efek perubahan di dunia fisik. Colarik dan Ball menambahkan, kampanye Anonymous melawan jaringan teroris transnasional merupakan kompetisi antar aktor nonnegara dengan aktor non-negara lainnya dalam ruang siber. Hal tersebut menegaskan ruang siber dapat diakses untuk maksud tertentu oleh berbagai pihak. ${ }^{65}$ Jika merujuk artikel tersebut maka kelonggaran struktur sesuai dengan kapasitas Anonymous sebagai aktor nonnegara dalam ruang siber. Ditambah lagi dengan sifat dari ruang siber itu sendiri yang memungkinkan partisipasi dari berbagai pihak dengan begitu saja. Sehingga partisipasi secara sukarela dan mandiri adalah hal utama dalam kampanye Anonymous melawan jaringan teroris transnasional.

Kerangka tindakan kolektif yang dilakukan dalam kampanye melawan jaringan teroris dihadirkan oleh Anonymous. Anonymous memberitahukan langkah untuk berpartisipasi dalam operasi. Seperti mekanisme pelaporan keberadaan akun media sosial milik teroris dengan tagar. Kemudian, Anonymous membantu juga agar warganet dapat melakukan aksi peretasan juga dengan menghadirkan berbagai macam panduan yang mengikuti

${ }^{65}$ A. Colarik dan R. Ball, "Anonymous Versus ISIS: The Role of Non-state Actors in Self-defense," Global Security and Intelligence Studies 2, no. 1 (2016): 29. kapasitas warganet. Tindakan kolektif tidak hanya sebatas pelaporan dan aksi peretasan. Jika melihat pada operasi Daeshbags maka tindakan kolektif yang disusun oleh Anonymous adalah membuat meme yang jenaka hasil kreasi dari warganet. Berdasarkan hal tersebut maka dapat dinyatakan Anonymous melakukan pembingkaian terhadap tindakan kolektif yang dapat dilakukan oleh partisipan dalam operasi yaitu pelaporan keberadaan akun media sosial yang berafiliasi dengan teroris, peretasan terhadap akun media sosial milik teroris, serta pembuatan meme anggota teroris. Berbagai tindakan kolektif tersebut dapat dinyatakan juga menjadi orientasi dari Anonymous itu sendiri untuk mewadahi berbagai bentuk partisipasi warganet dalam kampanye melawan jaringan teroris transnasional.

Berdasarkan artikel oleh Richards dan Wood dalam International Journal of Cyber Criminology, tindakan kolektif dalam kampanye melawan jaringan teroris oleh Anonymous tidak terlepas dari perilisan video untuk mensosialisasikan berbagai macam operasi. Video tersebut menghadirkan ketertarikan emosional terhadap khalayak umum untuk melakukan perlawanan terhadap teroris. Hal ini mendukung pelaksanaan pergerakan dengan menghadirkan berbagai makna yang bersifat politis. Selain itu, khalayak umum dapat merasa nilai-nilai penting mereka yang terancam oleh jaringan teroris terwakili oleh keberadaan pergerakan sosial transnasional. ${ }^{66}$ Dari artikel tersebut dapat dinyatakan kerangka tindakan kolektif yang dihadirkan oleh Anonymous tidak hanya teknis saja dengan panduan berpartisipasi dalam operasi. Namun, Anonymous juga memiliki kerangka tindakan kolektif yang mengarahkan emosi publik dengan

\footnotetext{
${ }^{66}$ I. Richards dan M. A. Wood, "Hacktivists against Terrorism: A Cultural Criminological Analysis of Anonymous' Anti-IS Campaigns," International Journal of Cyber Criminology 12, no. 1 (2018): 192-197.
} 
menegaskan nilai bermakna dalam video yang dirilis mereka. Dengan hal tersebut, partisipan kampanye dibingkai secara material dan ideasional.

Repertoar perlawanan dalam pergerakan sosial transnasional Anonymous melawan jaringan teroris terdiri dari klaim nilai-nilai yang terancam oleh keberadaan teroris serta klaim capaian setiap operasi. Dalam perilisan informasi diadakannya operasi, Anonymous tidak hanya memaparkan terjadinya aksi teror yang membuat perlu dilakukan suatu operasi tetapi juga retorika keberadaan teroris sebagai ancaman terhadap nilai tertentu. Nilai tersebut seperti kebebasan menyatakan pendapat dan toleransi antar umat beragama. Anonymous menyebut keberadaan teroris mencederai, menyerang, dan merenggut nilai-nilai tersebut. Selanjutnya, klaim capaian dari setiap operasi selalu diumumkan mengenai keberhasilan yang sudah diraih selama kampanye melawan teroris berlangsung. Contohnya adalah mengumumkan berhasil memusnahkan akun media sosial milik teroris, meretas situs daring milik teroris, dan mematikan jaringan komunikasi teroris dalam ruang siber. Berbagai klaim tersebut ditujukan untuk mendukung perkembangan dan keberlangsungan dari pergerakan serta penegasan Anonymous berada dalam posisi yang unggul, Lebih lanjut, dengan berbagai klaim tersebut mempertegas juga tujuan dari pergerakan sosial transnasional Anonymous yaitu memusnahkan teroris dalam ruang siber.

Berdasarkan artikel oleh Martins dalam Cyber Defense Review, kampanye Anonymous melawan jaringan teroris transnasional berintensitas cukup rendah. Berbagai operasi yang dilakukan memiliki efek berupa menurunkan dukungan aktivitas dan keefektifan ISIS secara bertahap. Aksi peretasan dan serangan siber yang dilakukan oleh Anonymous sebenarnya tidak akan menghasilkan tewasnya anggota ISIS atau kerusakan sumber daya fisik yang dimiliki mereka. Dengan hal tersebut, berbagai operasi dari Anonymous dilakukan secara terus-menerus untuk dapat memberikan efek yang kuat atau telak bagi jaringan teroris transnasional. ${ }^{67}$ Jika merujuk artikel tersebut maka dapat dikatakan klaim nilai yang terancam dan capaian setiap operasi merupakan hal penting untuk disampaikan oleh Anonymous kepada khalayak umum. Klaim nilai yang terancam di setiap operasi menghadirkan dasar untuk pelaksanaan operasi. Kemudian, klaim capaian kemenangan dari setiap operasi menghadirkan keunggulan diri yang mendukung keberlangsungan dari operasi.

Karakteristik kampanye Anonymous melawan jaringan teroris transnasional dapat dikatakan tidak terlepas dari sumber kekuatan relatif yang dimiliki oleh hacktivist yaitu kemudahan partisipasi, anonimitas, dan struktur yang longgar. Kemudahan partisipasi dihadirkan oleh Anonymous dengan memungkinkan bentuk kerangka tindakan kolektif yang beragam. Keberagaman tersebut antara lain peretasan, pelaporan, dan pembuatan meme. Ditambah lagi, keberagaman cara didukung oleh alat kerangka tindakan kolektif yang sebagian besar sudah tersedia dalam kehidupan sehari-hari yaitu komputer dan internet. Lebih lanjut, dukungan pelaksanaan kerangka tindakan kolektif disediakan juga oleh Anonymous dalam bentuk panduan. Anonimitas dan struktur yang longgar juga merupakan sumber kekuatan relatif yang memungkinkan Anonymous melakukan inisiasi berupa struktur mobilisasi dan repertoar perlawanan dalam kesempatan politik. Kedua kekuatan relatif tersebut membuat operasi yang dilakukan oleh Anonymous dapat berjalan dengan partisipasi kelompok peretas atau warganet secara sukarela dalam jumlah yang banyak.

\footnotetext{
${ }^{67}$ R. Martins, “Anonymous' Cyberwar Against ISIS and the Asymmetrical Nature of Cyber Conflicts," Cyber Defense Review 2, no. 3 (2017): 101.
} 
Muhammad Fikry Anshori | Hacktivist pada Pergerakan Sosial Transnasional: Kampanye

Anonymous melawan Jaringan Teroris Transnasional 2015-2016

Penyebaran informasi atau klaim terkait keberhasilan operasi didukung juga oleh keberadaan struktur yang bersifat longgar. Lebih lanjut, struktur yang longgar dan anonimitas menjadi pendukung Anonymous juga dalam mewadahi partisipasi dan perekrutan partisipan baru untuk operasi selanjutnya.

\section{Kesimpulan}

Artikel ini bertujuan untuk mendeskripsikan karakteristik pergerakan sosial transnasional dalam kampanye Anonymous melawan jaringan teroris transnasional. Kampanye Anonymous melawan jaringan teroris transnasional terdiri dari enam operasi terhadap AQAP dan ISIS yang berlangsung pada tahun 2015 hingga 2016. Berdasarkan analisis dan diskusi terhadap aktivitas kampanye tersebut dapat diketahui karakteristik pergerakan sosial transnasional yang berupa terjadinya aksi teror sebagai momentum untuk memulai dan melaksanakan kampanye, kelompok peretas dan warganet sebagai partisipan sukarela dan mandiri, aksi perlawanan kolektif dengan peretasan dan meme terhadap jaringan teroris, serta klaim teroris sebagai ancaman dan klaim kemenangan perlawanan terhadap teroris. Berbagai karakteristik tersebut memperlihatkan juga keberadaan ciri khas tersendiri yang dimiliki oleh Anonymous dalam posisi sebagai aktor non-negara dalam ruang siber serta sebagai hacktivist pada pergerakan sosial transnasional yaitu kemudahan cara berpartisipasi, anonimitas terjaga, serta struktur yang longgar.

Artikel ini masih memiliki kekurangan dan keterbatasan dengan hanya mendeskripsikan aktivitas kampanye oleh Anonymous terhadap jaringan teroris serta karakteristik pergerakan sosial transnasional yang ada di dalamnya. Perlu dilakukan kajian lebih lanjut untuk memahami pergerakan sosial transnasional oleh Anonymous terhadap aktor dalam hubungan internasional secara menyeluruh. Oleh karena itu, disarankan untuk kajian lanjutan berupa komparasi karakteristik pergerakan sosial transnasional antara kampanye Anonymous terhadap aktor nonnegara dengan kampanye Anonymous terhadap aktor negara. 
Muhammad Fikry Anshori | Hacktivist pada Pergerakan Sosial Transnasional: Kampanye

Anonymous melawan Jaringan Teroris Transnasional 2015-2016

\section{DAFTAR PUSTAKA}

A GUEST. "\#OPCHARLIEHEBDO." Pastebin. https://pastebin.com/uzaDjcmu (diakses 24 Juni 2019).

A GUEST. "5elafabook.com." Pastebin. https://pastebin.com/JdNiMA32 (diakses 24 Juni 2019).

Andreas, J. dan S. Winterfeld. Cyber Warfare: Techniques, Tactics and Tools for Security Practitioners, Waltham: Syngress, 2014.

Anonymous. "Anonymous Operation « Charlie Hebdo » \# Anonymous Operations." Anonymous. $\quad$ https://www.anonymous-france.eu/anonymous-operation-charliehebdo.html (diakses 24 Juni 2019).

Anonymous. "We are on the side of the oppressed \# Anonymous Operations." Anonymous. https://www. anonymous-france.eu/we-are-on-the-side-of-the-oppressed.html (diakses 24 Juni 2019).

Anonymous. "Anonymous \#OpParis \# Anonymous Operations." Anonymous. https://www.anonymous-france.eu/anonymous-opparis.html (diakses 24 Juni 2019).

Anonymous ArchAngel NetWork Media. "Anonymous \#OpBrussels." YouTube. https://www.youtube.com/watch?v=zBPHbCAo094 (diakses 24 Juni 2019).

Anonymous ArchAngel NetWork Media. "Anonymous \#OpNice." YouTube. https://www.youtube.com/watch?v=dQzDEBdo4ck (diakses 24 Juni 2019).

Anonymous France. "[ENG] Anonymous - \#OpCharlieHebdo." YouTube. https://www.youtube.com/watch?v=oqbwqmb8P00 (diakses 24 Juni 2019).

Anonymous Official. "Anonymous - Operation Paris \#OpParis." YouTube. https://www.youtube.com/watch?v=ybz59LbbACQ (diakses 24 Juni 2019).

Anonymous Official. "Anonymous - Operation Brussels \#OpBrussels." YouTube. https://www.youtube.com/watch?v=iJ82nPfWS_k (diakses 24 Juni 2019).

Anonymous WolfSec. "About." Facebook. https://www.facebook.com/pg/WolfSecurities/ about/ (diakses 12 Juni 2019).

Ban, I.. "Happy December 1 $11^{\text {th }}$." Twitter. https://twitter.com/Amidamaru_san/status/ 675233805997842437/photo/1 (diakses 24 Juni 2019).

BBC. “As It Happened: Charlie Hebdo Attack.” BBC. https://www.bbc.com/news/live/worldeurope-30710777 (diakses 24 Juni 2019).

BBC. "Charlie Hebdo Attack: Three Days of Terror." $B B C$. https://www.bbc.com/news/world-europe-30708237 (diakses 24 Juni 2019).

BBC. "Paris attacks: The investigation so far." $B B C$. https://www.bbc.com/news/worldeurope-34822265 (diakses 24 Juni 2019).

BBC. "Paris attacks: Who were the victims?" $B B C$. https://www.bbc.com/news/worldeurope-34821813 (diakses 24 Juni 2019).

BBC. "Paris attacks: What happened on the night." $B B C$. https://www.bbc.com/news/worldeurope-34818994 (diakses 24 Juni 2019).

BBC. "Brussels explosions: What we know about airport and metro attacks." $B B C$. https://www.bbc.com/news/world-europe-35869985 (diakses 24 Juni 2019).

BBC. "Brussels explosions: Why has Belgium's capital been attacked?." $B B C$. https://www.bbc.com/news/world-europe-35870957 (diakses 24 Juni 2019).

BBC, "Nice attack: What we know about the Bastille Day killings," $B B C$, https://www.bbc.com/news/world-europe-36801671 (diakses 24 Juni 2019).

BBC, "Nice attack: Witnesses describe Bastille Day terror," $B B C$, https://www.bbc.com/ news/world-europe-36801431 (diakses 24 Juni 2019). 
Muhammad Fikry Anshori | Hacktivist pada Pergerakan Sosial Transnasional: Kampanye Anonymous melawan Jaringan Teroris Transnasional 2015-2016

Bernik, I.. Cybercrime and Cyberwarfare, London: ISTE, 2014.

Brooking, E. T.. "Anonymous vs. The Islamic State." Foreign Policy. https://foreignpolicy.com/2015/11/13/anonymous-hackers-islamic-state-isis-chanonline-war/ (diakses 2 Juli 2019).

Carter, C. J.. "Video shows ISIS beheading U.S. journalist James Foley." CNN. https://edition.cnn.com/2014/08/19/world/meast/isis-james-foley/index.html (diakses 24 Juni 2019).

CFR Staff. "Al-Qaeda in the Arabian Peninsula (AQAP)." Council on Foreign Relations. https://www.cfr.org/backgrounder/al-qaeda-arabian-peninsula-aqap (diakses 12 Juni 2019).

CtrlSec. "CtrlSec.” Twitter. https://twitter.com/CtrlSec (diakses 12 Juni 2019).

CtrlSec. "Report Online Terrorism." Report Online Terrorism. http://reportonlineterrorism.com/ (diakses 12 Juni 2019).

CNN Library. "AQAP Fast Facts." CNN. https://edition.cnn.com/2015/06/16/ middleeast/aqap-fast-facts/index.html (diakses 12 Juni 2019).

CNN Library. "ISIS Fast Facts.” CNN. https://edition.cnn.com/2014/08/08/world/isis-fastfacts/index.html (diakses 12 Juni 2019).

Colarik, A. dan R. Ball. "Anonymous Versus ISIS: The Role of Non-state Actors in Selfdefense." Global Security and Intelligence Studies 2, no. 1 (2016): 20-32.

Counter Extremist Project. "Al-Qaeda in the Arabian Peninsula (AQAP)." Counter Extremist Project. https://www.counterextremism.com/threat/al-qaeda-arabian-peninsula-aqap (diakses 12 Juni 2019).

Counter Extremist Project. "ISIS,". Counter Extremist Project. https://www. counterextremism.com/threat/isis (diakses 12 Juni 2019).

CyberDB. "BinarySec." CyberDB: The Cyber Research Databank. https://www.cyberdb.co/vendor/binarysec/ (diakses 12 Juni 2019).

Delmas, C.. "Is Hacktivism The New Civil Disobedience?." Raisons Politiques, no 69 (2018): 63-81.

Esposito, J. L.. "Jihad." Oxford Islamic Studies Online. http://www.oxfordislamicstudies. com/article/opr/t125/e1199 (diakses 14 Juni 2019).

Esposito, J. L. "Pan-Islamism," Oxford Islamic Studies Online, http://www. oxfordislamicstudies.com/ article/opr/t125/e1819 (diakses 14 Juni 2019).

Esposito, J. L.. "Salafi." Oxford Islamic Studies Online. http://www.oxfordislamicstudies. com/article/opr/t125/e2072 (diakses 14 Juni 2019).

Esposito, J. L.. "Shariah." Oxford Islamic Studies Online. http://www.oxfordislamicstudies. com/article/ opr/t125/e2168 (diakses 14 Juni 2019).

Esposito., J. L.. "Sunni Islam." Oxford Islamic Studies Online. http://www. oxfordislamicstudies.com/article/opr/t125/e2280 (diakses 14 Juni 2019).

Esposito, J. L.. "Takfir." Oxford Islamic Studies Online. http://www.oxfordislamicstudies. com/article/opr/t125/e2319 (diakses 14 Juni 2019).

Flavio, A.. "Anonymous Vows to Avenge Terror Attack in Nice, Launches \#OpNice to Track Down ISIS Terrorists [Video]." AnonHQ. https://anonhq.com/anonymous-vowsavenge-terror-attack-nice-launches-opnice-track-isis-terrorists-video/ (diakses 24 Juni 2019).

Flavio, A.. "New Weapon for Fighting ISIS: Anonymous Attacks Twitter Accounts of Terror Group with Porn." AnonHQ. https://anonhq.com/new-weapon-fighting-isis-anonymousattacks-twitter-accounts-terror-group-porn/ (diakses 24 Juni 2019). 
Muhammad Fikry Anshori | Hacktivist pada Pergerakan Sosial Transnasional: Kampanye Anonymous melawan Jaringan Teroris Transnasional 2015-2016

FURIO. “Quack Quack!.” Twitter. https://twitter.com/incognito1570/status/ 675339334023782400/photo/1 (diakses 24 Juni 2019).

George, J. J. dan D. E. Leidner. "From Clicktivism to Hacktivism: Understanding Digital Activism." Information and Organization. https://doi.org/10.1016/j.infoandorg. 2019.04.001 (diakses 12 Juni 2019).

Ghost Security Group. "About." Ghost Security Group. https://ghostsecuritygroup.com/about-ghost-security-group/ (diakses 12 Juni 2019).

Ghost Security Group. "Capablities." Ghost Security Group. https://ghostsecuritygroup.com/ghost-security-group-capabilities/ (diakses 12 Juni 2019).

Gorton, T.. "Anonymous releases guide on how to hack ISIS." Dazed. https://www.dazeddigital.com/artsandculture/article/28484/1/anonymous-releasesguide-on-how-to-hack-isis (diakses 24 Juni 2019).

HalconNegro. "We love bacon." Twitter. https://twitter.com/pepeeltenso/status/ 675234069739909120/photo/1 (diakses 24 Juni 2019).

Hern, A.. "Anonymous 'at war' with Isis, hacktivist group confirms." The Guardian. https://www.theguardian.com/technology/2015/nov/17/anonymous-war-isis-hacktivistgroup-confirms (diakses 12 Juni 2019).

Houl, M.. "Anonymous- \#OpISIS Continues... Round 2.." YouTube. https://www.youtube.com/ watch?v=BPE_sRhZp6M (diakses 24 Juni 2019).

Hughes, R. B.. "How is the Cyber Revolution Changing Asia-Pacific National Security Concerns?." Dalam Asia-Pacific Security: An Introduction, diedit oleh J. Wallis \& A. Carr, 201-220. Washington DC: Georgetown University Press, 2016.

Huntington, S. P.. "Transnational Organizations in World Politics." World Politics 25, no. 3 (1973): 333-368.

John, T.. "Anonymous Launches 'Biggest Operation' Against ISIS in Response to Paris Attacks." TIME. http://time.com/4114182/anonymous-paris-attacks/ (diakses 12 Juni 2019).

Jordan, T.dan P. A. Taylor. Hacktivism and Cyberwars: Rebels with a Cause?, London: Routledge, 2004.

Kaiser, K.. "Transnational Politics: Toward a Theory of Multinational Politics.” International Organization 25, no. 4, (1971): 790-817.

Laub, Z.. "The Islamic State." Council on Foreign Relations. https://www.cfr.org/ backgrounder/islamic-state (diakses 12 Juni 2019).

McAdam, D., S. Tarrow, dan C. Tilly. Dynamics of Contention, New York: Cambridge University Press, 2001.

Machado, M. B.. "Between control and hacker activism:the political actions of Anonymous Brasil." História, Ciências, Saúde - Manguinhos 22, (2015): 1-18.

Mansfield, K.. "'Expect Us' Anonymous warn ISIS as thousands rally to troll evil terror group TODAY." Express. https://www.express.co.uk/news/world/625858/Expect-usAnonymous-warn-ISIS-thousands-troll-terrorists (diakses 24 Juni 2019).

Martins, R.. "Anonymous' Cyberwar Against ISIS and the Asymmetrical Nature of Cyber Conflicts." Cyber Defense Review 2, no. 3 (2017): 95-105.

Mikhaylova, G.. "The "Anonymous" Movement: Hacktivism as An Emerging of Political Participation." Master Thesis, Texas State University, 2014.

Mour, M.. “.” Twitter. https://twitter.com/funkyoulow/status/675278865028153345/photo/1 (diakses 24 Juni 2019). 
Muhammad Fikry Anshori | Hacktivist pada Pergerakan Sosial Transnasional: Kampanye Anonymous melawan Jaringan Teroris Transnasional 2015-2016

Namikaze, B.. "ANONYMOUS RELEASED 3 HOW TO HACK GUIDES AGAINST ISIS." Hacking Dream. https://www.hackingdream.net/2015/11/anonymous-released-3-howto-hack-guides.html (diakses 24 Juni 2019).

Nye, J. S., Jr.. The Future of Power, New York: Public Affairs, 2011.

Nye, J. S., Jr. dan R. O. Keohane. "Transnational Relations and World Politics: An Introduction.” International Organization 25, no. 3 (1971): 329-349.

Oracle. "What is Big Data?." Oracle. https://www.oracle.com/big-data/guide/what-is-bigdata.html (diakses 14 Juni 2019).

Paganini, P.. "Hacker Interviews - The Riddler, the founder of the BinarySec Group." Security Affairs. https://securityaffairs.co/wordpress/50886/hacking/hacker-interviewsbinarysec.html (diakses 12 Juni 2019).

Paganini, P.. "A group of hackers known as VandaSec claims three ISIS Twitter accounts trace back to computers belonging to the UK government." Security Affairs. https://securityaffairs.co/wordpress/42881/hacking/isis-twitter-linked-uk-govt.html (diakses 12 Juni 2019).

Paganini, P.. "Anonymous launches the OpISIS and brings down ISIS social media accounts." Security Affairs. https://securityaffairs.co/wordpress/33288/hacking/ anonymous-launches-opisis.html (diakses 24 Juni 2019).

Paganini, P.. "\#OpBrussells Anonymous 's revenge on ISIS after Brussels attacks." Security Affairs. https://securityaffairs.co/wordpress/45614/breaking-news/anonymousopbrussels.html (diakses 24 Juni 2019).

Pendegrass, W. S. "What is Anonymous?: A Case Study of An Information Systems Hacker Activist Collective Movement." Doctoral dissertation, Robert Morris University, 2013.

Perez, C.. "Anonymous attacks ISIS supporters online." New York Post. https://nypost.com/2015/02/10/hacking-group-anonymous-attacks-isis-supportersonline/ (diakses 12 Juni 2019).

Podolny, J. M. dan K. L. Page. "Network Forms of Organization." Annual Review of Sociology, vol. 24 (1998): 57-76.

Reinsigner, D.. "Anonymous Declares Cyber War on ISIS. Why It Matters." Fortune. http://fortune.com/2015/11/16/anonymous-cyber-war-isis/ (diakses 12 Juni 2019).

Reveron, D. S.. "An Introduction to National Security and Cyberspace." Dalam Cyberspace and National Security: Threats, Opportunities and Power in a Virtual World, diedit oleh D. S. Reveron, 3-19. Washington D.C.: Georgetown University Press, 2012.

Richards, I. dan M. A. Wood. "Hacktivists against Terrorism: A Cultural Criminological Analysis of Anonymous' Anti-IS Campaigns." International Journal of Cyber Criminology 12, no. 1 (2018): 192-197.

Righteous. "OpISIS: A Chronology of Events." AnonHQ. https://anonhq.com/opisis-achronolgy/ (diakses 24 Juni 2019).

Risse, T.. "Transnational Actors and World Politics." Dalam Handbook of International Relations, diedit oleh W. Carlsnaes, T. Risse, dan B. A. Simmons, 426-452. London: SAGE, 2013.

Risse-Kappen, T.. "Bringing Transnational Relations Back In: Introduction.” Dalam Bringing Transnational Relations Back In: Non-State Actors, Domestic Structures and International Institutions, diedit oleh T. Risse-Kappen, 3-33. New York: Cambridge University Press, 1998.

Rogers, K.. "Anonymous Hacker Fight ISIS but Reactions Are Mixed." The New York Times. https://www.nytimes.com/2015/11/26/world/europe/anonymous-hackers-fight-isis-butreactions-are-mixed.html (diakses 12 Juni 2019). 
Muhammad Fikry Anshori | Hacktivist pada Pergerakan Sosial Transnasional: Kampanye Anonymous melawan Jaringan Teroris Transnasional 2015-2016

Samuel, A. W.. "Hacktivism and the Future of Political Participation." PhD dissertation, Harvard University, 2004.

Segall, L.. "Meet the hacker fighting ISIS with porn." $C N N$. https://money.cnn.com/2016/06/16/ technology/isis-hacker-porn-gay-pride/index.html (diakses 12 Juni 2019).

Shakarian, P., J. Shakarian, \& A. Ruef. Introduction to Cyber-Warfare: A Multidisciplinary Approach, Waltham: Syngress, 2013.

Singer, P. W. dan A. Friedman. Cybersecurity and Cyberwar: What Everyone Needs to Know, New York: Oxford University Press, 2014.

Sorell, T.. "Human Rights and Hacktivism: The Cases of Wikileaks and Anonymous." Journal of Human Rights Practice 7, no. 3 (2015): 391-410.

Springer, P. J.. Cyber Warfare: A Reference Handbook, Santa Barbara: ABC-CLIO, 2015.

Tarrow, S., "Transnational Politics: Contention and Institution in International Politics," Annual Review of Political Science, vol. 4, (2001):1-20.

Tarrow, S.. The New Transnational Activism, New York: Cambridge University Press, 2005.

Tarrow, S.. Power in Movement: Social Movements and Contentious Politics, New York: Cambridge University Press, 2011.

Techopedia. "Internet Protocol Address (IP Address)." Techopedia. https://www.techopedia.com/definition/2435/internet-protocol-address-ip-address (diakses 14 Juni 2019).

Vandita. "Anonymous Takes Down ISIS Websites, Confirms Leaked Government Documents Were Real." AnonHQ. https://anonhq.com/anonymous-takes-isis-websitesconfirms-leaked-government-documents-real/ (diakses 24 Juni 2019).

WauchulaGhost. "About the Ghost." Wauchula Ghost: The Ghost of No Nation. https://wauchulaghost.com/about/ (diakses 12 Juni 2019).

Willetts, P.. "Transnational Actors and International Organizations in Global Politics." Dalam The Globalization of World Politics: An Introduction to International Relations, diedito oleh J. Baylis, S. Smith, \& P. Owens, 320-336. New York: Oxford University Press, 2014.

Winchester, L.. "Twitter swamped with images mocking ISIS \#Daeshbags as Anonymous trolling day kicks off." Expres., https:/www.express.co.uk/news/world/626003/ Islamic-State-Daesh-trolling-day-Anonymous-OpISIS-Daeshbags (diakses 24 Juni 2019).

Winterfeld, S. dan J. Andreas. The Basic of Cyber Warfare: Understanding the Fundamentals of Cyber Warfare in Theory and Practice, Waltham: Syngress, 2013

Wright, J. M. "Digital Contention: Anonymous and the Freedom of Information Movement." Master thesis, Purdue University, 2012.

Zakrewski, C.. "Hacking Collective Anonymous Declare Total War On ISIS Following Paris Terror Attacks." Tech Crunch. https://techcrunch.com/2015/11/16/hacking-collectiveanonymous-declares-total-war-on-isis-following-paris-terror-attacks/ (diakses 12 Juni 2019).

\section{BIOGRAFI}

Muhammad Fikry Anshori Alumni Program Sarjana Hubungan Internasional, Fakultas Ilmu Sosial dan Ilmu Politik, Universitas Padjadjaran angkatan 2015. Minat Hubungan Internasional meliputi Keamanan Non-Tradisional, Transnasionalisme, Rezim Internasional, dan Diplomasi Publik. 